\title{
Komunikasi dan dukungan sosial di lingkungan masyarakat terdampak pembangunan Waduk Jatigede Sumedang
}

\author{
Agus Rahmat ${ }^{1}$, Kokom Komariah ${ }^{2}$, dan Wawan Setiawan ${ }^{3}$ \\ 1,2,3 Universitas Padjadjaran, Bandung, Indonesia
}

\begin{abstract}
ABSTRAK
Bagi masyarakat yang menjadi terdampak dari pembangunan bendungan Jatigede, persoalan yang dihadapi pasca penggenangan tidak terhenti hanya sampai pada penerimaan uang ganti rugi dan pemukiman kembali diri serta keluarga di tempat yang baru, akan tetapi persoalan yang dihadapi saat ini jauh lebih sulit seperti menyangkut pekerjaan guna menyambung kehidupan diri dan keluarga dan adaptasi diri dan keluarga pada lingkungan yang baru. Sebagai mahluk sosial, persoalan yang dirasa jauh lebih penting terkait dengan adaptasi dengan orang-orang baru baik lingkungan tetangga ataupun lingkungan warga. Kemampuan bertahan dalam lingkungan sosial yang baru ini menjadi keniscayaan untuk kelangsungan hidup orangorang terdampak pembangunan waduk Jatigede. Masalahnya adalah apakah lingkungan sosial yang baru mendorong kemampuan bertahan dari orang-orang terdampak pembangunan waduk Jatigede atau tidak. Untuk mengetahui kondisi ini, penelitian dilakukan di dua wilayah yaitu wilayah relokasi dan di wilayah sisipan pemukiman kembali. Penelitian ini menggunakan pendekatan kuantitatif atau paradigma positivis, sedangkan untuk dukungan sosial yang dinilai dalam penelitian ini meliputi empat aspek meliputi dukungan emosional, dukungan nyata, dukungan kasih sayang dan interaksi sosial. Hasil kajian menunjukan bahwa dukungan sosial menentukan ketahanan sosial orang-orang terdampak pembangunan waduk Jatigede, baik secara total (gabungan) maupun secara parsial. Adapun hasil perhitungan secara parsial menunjukan bahwa diantara dukungan sosial yang ada, dukungan emosional merupakan dimensi dukungan sosial yang memiliki pengaruh yang paling besar terhadap ketahanan ataupun kemampuan adaptasi dari orang-orang terdampak pembangunan Jatigede.
\end{abstract}

Kata-kata Kunci: dukungan sosial; ketahanan; lingkungan; orang terdampak; pemukiman kembali

\section{Communication and social support on community resiliance around Jatigede Dam in Sumedang}

\begin{abstract}
For the community affected by the development of Jatigede Dam in Sumedang, West Java, Indonesia,the problems faced after the drowning was not stopped only on the compensation given and resettlement to individual and his familiy in new locations. The problems faced recently is far more difficultsince they are related to new jobs to sustain his lifes and his family, and also in adaptation in the new environment. As social human beings, the problems that are far more difficult is related to adaptation with new people, both their neighbors or the community is expected to give positive impact for the society. The abilites to survive in the new social environment become neccesary for sustainable long living of the people affected by the development of Jatigede Dam. The questions are whether or not the new social environment has supported the survival ability of the people affected by the development of Jatigede Dam. In terms of finding out the existing condition, the research is conducted in two locations, that is relocation area and insertion area of resettlement. The research used quantitative approach or positivist paradigm, whereas social supports determined in the research included four aspects which are emotional supports, real supports, care supports, and social interaction. The result shows that social support has determined social sustainability of the people effected by the development of Jatigede, either totally or partially. Moreover, the result of partial calculation shows that among the existing social support, emotion support appeared as social support dimension that having the biggest influences toward the sustainabilty or adaptation ability of the people affected by development of Jatiluhur Dam.
\end{abstract}

Keywords: affected communities; new environment; resettlement; resilience; social support

Korespondensi: Dr. Agus Rahmat, M.Pd. Universitas Padjadjaran, Jln Raya Bandung Sumedang, KM 21 Jatinangor.Email: agus.rahmat@unpad.ac.id 


\section{PENDAHULUAN}

Terkait dengan infrastruktur bendungan (dam) di dunia saat ini (Kirchherr \& Charles, 2016), menyebutkan bahwa saat ini sedang berlangsung ledakan global pembangunan bendungan, bahkan menurut catatan keduanya disebutkan di tahun 2014 bendungan yang dibangun mencapai 3.700 buah bendungan. Banyak alasan yang menbenarkan pembangunan bendungan dilakukan secara terus menerus di berbagai negara. (Kirchherr \& Charles, 2016) menyebut beberapa alasan pembuatan bendungan, seperti terkaitnya bendungan dengan kontribusi pada aspek ekonomi, lingkungan, juga keuntungan sosial. Penulis lain Cartney dkk memerinci mengenai beberapa aspek terkait dengan pembangunan bendungan seperti rekreasi, pengendalian banjir, pasokan air, tenaga air, pengelolaan limbah, navigasi sungai serta habitat satwa liar, juga menulis bahwa bendungan menghasilkan peluang mata pencaharian baru seperti pariwisata, transportasi, dan lain-lain (Mccartney, Sullivan, \& Acreman, 2001). Keuntungan sebagaimana dikemukakan beberapa penulis tadi sejalan dengan para penulis lain seperti (Kirchherr \& Charles, 2016) menulis mengenai bendungan sebagai pembangkit listrik terbesar di dunia saat ini.

Pembuatan bendungan dimasa datang diprediksi akan tetap tinggi terkait dengan beberapa alasan seperti semakin banyaknya kebutuhan terkait dengan air, populasi penduduk yang terus meningkat, juga kebutuhan akan energi yang terus berkemban. (Mccartney et al., 2001) berpendapat bahwa "kedepan, seiring meningkatnya populasi dan konsumsi air, banyak orang percaya akan kebutuhan bendungan yang lebih banyak. Namun selain keuntungan yang didapat oleh manusia dari pembangunan bendungan, pembangunan bendungan ini juga tidak sedikit memberi pengaruh negatif(Lerer, 1999) mengidentifikasi paling tidak tujuh dampak sosial pembangunan bendungan, yaitu: daerah tangkapan dan sungai hulu; daerah waduk; sungai hilir; daerah irigasi; kegiatan konstruksi; daerah pemukiman kembali dan negara, regional dan global. Selanjutnya (Shields, 2015) juga menyebut bahwa salah satu dampak sosial dari pembangunan bendungan adalah terkait dengan persoalan pemukiman kembali. Dampak pemukiman kembali ini telah banyak menjadi sorotan para ahli sosial karena terkait dengan persoalan tanggapan sistem sosial berupa restrukturisasi lingkungannya.

Dampak atas pemukiman kembali dari orang-orang terdampak pembangunan Jatigede juga merupakan hal menarik bagi peneliti karena dua alasan. Pertama terkait dengan banyaknya orang yang menjadi terdampak. Sekalipun tidak ada catatan yang pasti seperti dikatakan (Lidahuli, 2015), dan diperkirakan oleh Sakwa bahwa sampai tahun 2012 saja sekitar 250-300 juta orang sudah direlokasi (Lidahuli, 2015). Dan negara-negara yang banyak melakukan kegiatan ini adalah negaranegara berkembang baik di Asia, Amerika Selatan, dan Afrika (Badri, Asgary, Eftekhari, \& Levy, 2006); (Pietkiewicz, Wojcik, Popiolek, \& Barika, 2015). Dalam tulisan peneliti ini juga disebutkan mengenai dua negara tertinggi melakukan relokasi pemukiman ini yaitu China yang mencapai 70 juta selama periode 19502008, dan India yang mencapai 60 juta Jiwa (Pietkiewicz et al., 2015)

Alasan kedua terkait dengan efek yang ditimbulkan dari kegiatan pemukiman kembali. Efek pemukiman kembali tidak hanya perubahan tempat(Downing, 2002) menyebutkan beberapa dampak pemukiman kembali ini seperti "hilangnya aset fisik dan non-fisik, termasuk rumah, masyarakat, lahan produktif, aset dan sumber pendapatan produktif, subsisten, sumber daya, situs budaya, struktur sosial, jaringan dan ikatan, identitas budaya dan mutual mekanisme kesehatan. Dampak yang disebutkan (Downing, 2002) sejalan juga dengan ahli lain seperti (Cernea, 1997) seperti hilangnya kemungkinan penghidupan atau pekerjaan, dalam proses pemukiman kembali peluang semacam itu seringkali tidak tersedia di lokasi baru, termasuk mengurangi kapasitas organisasi ekonomi suatu kelompok. Kalaupun selanjutnya masyarakat terdampak ini dimukimkan dengan cara disebar di tengah-tengah masyarakat yang sudah ada dan mapan, persoalan tetap muncul seperti temuan dari kajian (Pietkiewicz et al., 2015) yang menganalisis hasil risetnya (Cernea, 1997), (Downing, 2002), (Cline, 2016) menyimpulkan bahwa pemukiman pola seperti ini cenderung akan merusak pola dan kontinuitas masyarakat yang dimasuki.

(Kirchherr \& Charles, 2016) menyebutkan bahwa pemukiman menimbulkan dampak pada jaringan sosial dan status, modal dan solidaritas, 
kebahagiaan, tekanan sosial. Hal yang sama juga dikemukakan (Mccartney et al., 2001) yang mengemukakan bahwa "Dampak sosial dari modifikasi hidrologi dapat mencakup pemindahan paksa populasi, migrasi, gangguan sosial, hilangnya akses terhadap sumber daya, kehilangan modal budaya, dan penipisan sumber daya alam".

Secara tegas nampak bahwa pemukiman kembali masyarakat terdampak membawa dampak yang jauh melebihi kehilangan tanah sehingga butuh penanganan yang benar. Temuan Oliver Smith atas ketiadaan penanganan yang benar adalah tingginya tingkat kematian atau fenomena "sekarat karena patah hati." Karenanya (Mccartney et al., 2001) menyarankan dalam pelaksanaan pemukiman kembali dilengkapi dengan sumber daya dan program yang memberi kesempatan berbagi manfaat untuk semua.

Tingginyatingkatkematian padamasyarakat yang terdampak seperti dikemukakan (Mccartney et al., 2001) diasumsikan terkait dengan stres yang tinggi pada tahap adaptasi. (Cobb, 1976) dan (Cobb, 1976) menuliskan bahwa "transisi dalam hidup menempatkan orang pada stress yang tinggi." Menghadapi hal semacam ini maka pemerintah sebagai representasi negara berkewajiban melakukan penanganan secara benar. Fakta dan aturan dasar di berbagai negara memang menunjukan bahwa, kegiatan pemukiman kembali berada di tangan negara, ini bisa diartikan bahwa salah satu yang perlu diperhatikan pemerintah dalam melaksanakan pemukiman kembali adalah mengurangi stres orang terkena dampak saat mereka beradaptasi di lokasi pemukiman baru, melalui pengembangan dukungan sosial.

Simpulan yang didapat oleh Smith atas terhadap tulisan ataupun kajian para ahli menurut (Chib \& Wilkin, 2013) adalah, untuk mengurangi stres masyarakat terdampak saat beradaptasi adalah membangun dukungan sosial, atau dukungan sosial demikian penting untuk mengurangi stres atau "sekarat karena patah hati".

Salah satu bendungan (dam) yang cukup besar dan baru dibangun serta masih menyisakan sederet persoalan yang sampai saat ini masih belum bisa dituntaskan seperti diberitakan Pikiran Rakyat.com tanggal tanggal 13 Januari 2018, adalah Bendungan Jatigede yang berada di Kabupaten Sumedang Jawa Barat. Berdasarkan pemberitaan Radar Sumedang, orang yang terdampak pembangunan waduk Jatigede ini diperkirakan mencapai 11.000 lebih KK. Pemukiman kembali orang-orang terdampak ini ada yang direlokasi oleh pemerintah dan ada juga yang tidak di relokasi, artinya masyarakat terdampak sendiri yang mencari tempat dan membangun kembali tempat tinggalnya di tengah-tengah masyarakat di wilayah lain (dikenal dengan pola sisipan). Orang-orang terdampak ini berasal dari Kecamatan Jatigede yang terdiri atas Desa Ciranggem, Jemah, Mekar asih, dan Sukakersa; Kecamatan Jatinunggal berasal dari Desa Pawenang dan Simasari; Kecamatan Wado berasal dari Desa Wado, Cisurat dan Padajaya; serta Kecamatan Darmaraja berasal dari Desa Cibogo, Cipaku, Jatibungur, Karangpakuan, Leuwihideung, Pakualam, Sukamenak, Sukaratu, Tarunajaya, dan Cikeusi.

Untuk memperoleh ketepatan dan kecepatan membangun ketahanan sosial masyarakat terdampak pembangunan Jatigede, pada tataran awal perlu diketahui peta dukungan sosial serta peta dari tingkat resiliensi dari orang-orang terdampak itu sendiri. Peta dasar ini berguna sebagai dasar untuk menyusun rancangan program bagi orang terdampak. Pentingnya pemetaan bagi kegiatan ini secara tegas telah dikemukakan beberapa peneliti seperti (Pokharel, 2009). Adapun pentingnya pemahaman atas ketahanan yang ada saat ini bagi pembangunan dikemukakan (Westley et al., 2011) dan (Cline, 2016) berpendapat bahwa memahami ketahanan dapat membantu inovator (pelaku perubahan) sosial untuk menyusun solusi atau penanggulangan persoalan yang dihadapi.

Dalam penelitian ini pemetaan atas dukungan sosial serta katahanan berpangkal pada beberapa konsep yang sudah banyak dipakai dalam mengkaji pengaruh lingkungan sosial terhadap perilaku manusia, seperti pengaruh dukungan sosial terhadap ketahanan masyarakat, termasuk masyarakat terdampak sebuah pembangunan pada beberapa kajian terdahulu, seperti konsep dan hasil kajian mengenai ketahanan dalam kaitannya dengan pengurangan stres pada orang rentan (Cohen, 2004).

Orang terdampak pembangunan Jatigede tergolong menjadi orang yang rentan terkait dengan kondisi perubahan lingkungan yang 
mengitarinya baik terkait dengan mata pencaharian, lingkungan alam ataupun perubahan lingskungan sosialnya.

Perubahan dalam mata pencaharian dan perubahan lingkungan menuntut orang terdampak melakukan adaptasi pada lingkungan atau tempat tinggal yang baru. Masa seperti ini merupakan masa yang strategis terkait dengan keberlanjutan dan keberhasilan seseorang khususnya masyarakat terdampak diterpa stres (selanjutnya disebut resiliensi). (Cobb, 1976) dan (Leary \& Derosier, 2012) menyebutkan masa transisi dalam hidup menempatkan orang pada resiko stres.

Konsep pokok lain dari penelitian ini menyangkut dukungan sosial. Konsep dukungan sosial menjadi konsep utama terkait dengan kenyataan bahwa dari sekian banyak faktor determinan stres bagi masyarakat khususnya orang-orang terdampak adalah dukungan sosial. Hasil kajian yang dilakukan para ahli menunjuk pada satu inti pemikiran bahwa secara tegas dukungan sosial dapat meningkatkan ketahanan terhadap stres, seperti penilitian (Leary \& Derosier, 2012) .

Dukungan sosial didefinisikan (Lin, Dean, \& Ensel, 1985) dan (Camara, Bacigalupe, \& Padilla, 2015) sebagai ketentuan instrumental dan / atau ekspresif, nyata atau dirasakan, yang diberikan oleh masyarakat, jaringan sosial, dan hubungan intim. Menurut (Cohen, 2004) dan (Sippel, Pietrzak, Mayes, \& Southwick, 2015) arti dukungan sosial mengacu pada penyediaan sumber daya psikologis dan material jejaring sosial yang ditujukan untuk memberi manfaat bagi kapasitas individu untuk mengatasi stres.

Dukungan sosial mencakup banyak bentuk. Menurut (Camara et al., 2015) bentuk dukungan mencakup atas, dukungan emosional atau fungsional dan dukungan instrumental. Lebih jauh disebutkan bahwa yang disebut dukungan emosional, terkait dengan perasaan nyaman yang membuat orang percaya bahwa dia dicintai, dihormati, dan/atau dirawat oleh orang lain; sementara yang disebut dengan dukungan instrumental/material mencakup atas barang dan jasa yang membantu memecahkan masalah praktis; serta dukungan informasi/ kognitif. Selain kelompok ini, menurut (Jairam \& Kahl, 2012) ada juga kelompok lainnya seperti (Kenneth \& Karen, 1997), (House \& Kahn, 1985), (Millicent \& Jeff, 2008), (Rosenholtz, 1989), (Schaefer, Coyne, \& Lazarus, 1981),
(Singh \& Billingsley, 2010) Menurut kelompok ini bentuk dukungan sosial atas dukungan emosional (upaya untuk mengurangi dampak negatif), dukungan profesional (pendampingan dan bimbingan), dan dukungan praktis (uang atau bantuan penyelesaian tugas).

Sippel dkk. menyebut tiga bentuk dari dukungan sosial yaitu:

dukungan struktural, yaitu ukuran dan luas jaringan sosial individu, frekuensi interaksi sosial; dukungan fungsional, yaitu pengalaman atau persepsi bahwa interaksi sosial telah bermanfaat dalam hal kebutuhan emosional atau instrumental; dukungan emosional, yaitu perilaku yang menumbuhkan perasaan nyaman yang membuat orang percaya bahwa dia dicintai, dihormati, dan/atau dirawat oleh orang lain (Sippel et al., 2015).

Jenis dukungan sosial yang saat ini banyak pengaruhnya adalah jenis dukungan sebagaimana dikemukakan (Sherbourne \& Stewart, 1991) mencakup atas: dukungan emosional, dukungan nyata, dukungan kasih sayang, dan interaksi sosial. Hal yang harus diperhatikan betul adalah dukungan sosial akan membawa arti dan kebaikan bagi orang tertentu dan dalam kondisi tertentu, dukungan sosial mungkin juga tidak meberi makna dan kebaikan bahkan memperburuk keadaan (Folke, 2016) pada intinya dukungan sosial yang diberikan pada orang terdampak membutuhkan kehatian hatian.

Keberhasilan dari dukungan lingkungan sosial yang diberikan kepada orang terdampak pembangunan Jatigede pada akhirnya tidak lagi memunculkan persepsi pembangunan bendungan jatigede sebagai kegiatan yang mengorbankan mereka dan hanya memberi dampak kebaikan terhadap mereka yang ada di hilir bendungan (manajemen untuk air pertanian, pengelolaan banjir, dll), melainkan tumbuhnya rasa bahwa kehadiran bendungan Jatigede benar-benar memperhitungkan dan memaksimalkan kebutuhan semua kelompok dalam masyarakat (Mccartney et al., 2001) dan semua ini bermula dari kemampuan orang-orang terdampak melalui dan beradaptasi dengan kehidupan baru. Secara singkat disebut bahwa dukugan sosial diberikan untuk menjadikan orang terdampak pembangunan Jatigede sebagai orang yang tahan terhadap perubahan. 
Konsep ketahanan atau resilien merupakan konsep yang banyak dikaji terkait dengan beberapa pertimbangan yang berlansung di dunia, seperti perubahan alam termasuk cuaca, munculnya berbagai bencana yang tidak sedikit merengut jiwa manusia. Sebagai kajian yang relatif baru, menjadi tidak mengherankan jika konsep ketahanan atau resiliensi ini masih terjadi perbedaan, satu satunya kesepakatan dari konsep ini adalah ketidak sepakatannya.

Beberapa definisi yang menunjukan keragaman konsep resiliensi bisa dilihat dalam Scholarly articles for Community Resilience: Conceptual Framework and Measurement Feed the Future Learning tahun 2013, dari (Cadell, Karabanow, \& Sanchez, 2001) yang mendefinisikan ketahanan sebagai "Kemampuan untuk beradaptasi dengan, mengatasi dan bahkan diperkuat oleh keadaan yang merugikan", sampai pemikiran UNDP (UNDP, 2013) yang menyebutkan resiliensi sebagai "Proses transformatif dari penguatan kapasitas masyarakat untuk mengantisipasi, mencegah, memulihkan, beradaptasi dan/ atau mengubah dari guncangan, tekanan dan perubahan".

Berdasarkan pengertian yang dikemukakan para ahli tercatat beberapa karakteristik pengertian yang diberikan para ahli. Kelompok ahli pertama, adalah mereka yang menekankan ketahanan sebagai kondisi yang ada, sementara kelompok ahli lainnya menekankan pada proses. akan tetapi dari definisi-definisi tersebut kalau diruntut menunjukan pada satu kesamaan, yaitu memuat kata "mampu menghadapi". Dengan demikian maka, kata "resiliensi" bisa diartikan sebagai kemampuan seseorang untuk menghadapi setiap terpaan yang menimpa dirinya.

Sebagai sebuah kemampuan, keberadaan resilience pada seseorang tentunya tidak muncul begitu saja, atau keberadaannya bukan merupakan sebuah keadaan yang "given". Resilience merupakan hasil dari sebuah proses, ini berarti bahhwa setiap manusia bisa memiliki kemampuan untuk menjadi resilience asalkan orang mau dan mampu untuk belajar bagaimana menghadapi rintangan dan hambatan dalam hidupnya. Sebagai konsekuensinya maka ketahanan seorang individu dapat berubah dari waktu ke waktu karena ia sebagai hasil bentukan dari interaksi seseorang dengan lingkungan (Southwick, Litz, Charney, \& Friedman, 2011).
Pemikiran ahli sebagaimana diungkapkan menunjukan pada dua faktor, yaitu belajar dan aspek lingkungan. Hal ini sejalan juga dengan apa yang dikatakan (Mitchell, 1987) bahwa "... all behavior is learned and environmentally (externally) determined." Oleh karena itu (Norris, 2008) yang menegaskan bahwa empat kapasitas adaptif kunci yang paling penting untuk masyarakat tangguh: pembangunan ekonomi, modal sosial, informasi dan komunikasi, dan kompetensi masyarakat.

Pemikiran yang dikemukakan para pakar yang dideskripsikan sebelumnya menjadi petunjuk bahwa ada pengaruh dari dukungan sosial yang diberikan komunitas sekitar terhadap ketahanan orang-orang terdampak sebuah program (pembangunan bendungan Jatigede). Dan dengan demikian maka dalam penelitian ini dapat dirumuskan empat hipotesis, yaitu: pertama Ada pengaruh dukungan emosional komunitas sekitar terhadap resiliensi orang terdampak pembangunan bendungan Jatigede; kedua, ada pengaruh dukungan nyata komunitas sekitar terhadap resiliensi orang terdampak pembangunan bendungan Jatigede; ketiga, ada pengaruh dukungan kasih sayang komunitas sekitar terhadap resiliensi orang terdampak pembangunan bendungan Jatigede; dan keempat, ada pengaruh interaksi positif komunitas sekitar terhadap resiliensi orang terdampak pembangunan bendungan Jatigede.

Dalam penelitian ini, diarahkan pada upaya untuk memetakan dukungan sosial orang terdampak pembangunan di lingkungan tempat tinggal baru (baik di wilayah relokasi maupun di wilayah sisipan). Dan untuk kepentingan analisa, dalam penelitian ini aspek dukungan sosial diposisikan sebagai variabel bebas sedangkan aspek ketahanan dari orang terdampak pembangunan bendungan Jatigede di posisikan sebagai variabel terikat.

\section{METODE PENELITIAN}

Penelitian ini bertujuan mengetahui pengaruh atas dukungan sosial terhadap ketahanan masyarakat terdampak pembangunan Jatigede. Sebagai konsekuensi tujuan ini maka penelitian ini menggunakan pendekatan positivistik atau pendekatan kuantitatif. Metode yang digunakan dalam penelitian ini adalah metode deskriptif yang menggambarkan masalah berdasarkan sifat data kualitatif 
sehingga dapat diperoleh pemahaman yang lebih mendalam tentang masalah yang diteliti (Bakti, Dewi, Romli, \& Budiana, 2015).

Populasi yang diartikan sebagai "Kumpulan objek penelitian yang digunakan untuk memperoleh data yang diperlukan atau keseluruhan unit sampling yang memiliki ciriciri yang sama menurut kriteria penelitian yang sedang dilakukan" (Rakhmat, 2009). Oleh karenanya populasi dalam penelitian ini adalah orang terdampak pembangunan waduk Jatigede.

Pemukiman orang terdampak pembangunan waduk Jatigede terbagi atas dua pola terbagi dalam dua model yaitu model relokasi (lokasi tempat tinggal baru disediakan pemerintah namun rumah di buat sendiri oleh terdampak) dan model sisipan (tanah dan rumah diupayakan sendiri oleh orang terdampak dari uang pengganti). Atas dasar pertimbangan ini maka partisipan dalam penelitian ini berasal dari dua kelompok (relokasi dan sisipan). Hasil perhitungan statistik jumlah partisipan dalam penelitian ini mencapai 98 orang terdampak, kemudian dibulatkan menjadi 100 (seratus) partisipan.

Jumlah partisipan dari kelompok relokasi lebih banyak dibanding dengan partisipan dari wilayah sisipan dengan dasar pertimbangan pertama jumlah kepala keluarga yang ikut relokasi lebih banyak dibanding dengan pola sisipan, kedua pengadministrasian orang terdampak dengan pola sisipan kurang bagus. Kondisi yang terjadi di wilayah Jatigede ini nampaknya tidak banyak berbeda dengan apa yang digambarkan (Lidahuli, 2015) mengenai kesulitan melacak orang terdampak.

Sebagai sebuah penelitian yang menggunakan pendekatan kuantitatif, pengumpulan data dalam penelitian ini lebih mengandalkan pedoman wawancara berupa angket. Yang di mana pengumpulan data dengan menggunakan angket/kuesioner dilakukan dengan cara memberikan sejumlah pertanyaan kepada responden untuk memperoleh data primer (Anisa, 2016). Untuk aspek dukungan sosial, dimensi yang dikaji lebih berdasar pada pemikiran (Miles, 2014) sedangkan untuk aspek resiliensi mengacu pada resilience scale (RS) 15. Dalam penelitian ini data utama diperoleh berdasarkan atas angket yang terstandar (resilience scale 15) yang disesuaikan dengan lingkungan budaya yang didukung oleh beberapa sumber data lain yang berasal dari: dokumen, rekaman arsip, wawancara, observasi langsung. Dalam aktivitas observasi ini peneliti mengamati secara langsung kegiatan seharihari subyek penelitian.

Pengamatan juga dilakukan peneliti dengan mengupayakan dua hal, yaitu informasi mengenai apa yang terjadi dan konteks atau hal-hal yang ada disekitar lokasi penelitian tapi yang berkaitan dengan tema utama penelitian. Wawancara yang dilakukan peneliti lebih bersifat informal dalam arti spontan, dalam suasana santai, namun tetap menggunakan daftar pertanyaan yang lebih rinci, dan terstruktur (angket baku dari ahli psikologi sosial). Hal ini sesuai dengan apa yang dinyatakan oleh (Nugraha, Sumartias, Novianti, \& Komariah, 2015) bahwa dalam suatu penelitian, peneliti memiliki definisi jelas tentang subyek dan objek penelitian yang akan dijadikan sebagai sumber informasi dengan menggunakan beberapa pertanyaan untuk mendapatkan informasi yang dibutuhkan. Untuk memperkuat hasil lapangan peneliti juga menggunakan studi kepustakaan. Beberapa jenis dokumen yang menjadi sumber data dalam penelitian ini antara lain: surat pengumuman resmi; beberapa agenda dan kesimpulan pertemuan, serta laporan peristiwa tertulis; termasuk informasi dari media terlembaga (dinilai memiliki kredibilitas tinggi).

Untuk mengetahui keberadaan dari dukungan sosial dengan ketahanan sosial, penelitian menggunakan analisa regresi. Untuk analisa relasi dari dukungan dengan ketahanan, digunakan analisa regresi simultan. Sementara untuk analisa setiap dimensi dukungan sosial dengan ketahanan sosial menggunakan analisa regresi berganda, dengan katagorisasi yang diagunakan mengacu pada corelasi Pearson, yaitu nilai Pearson Correlation: $0,00 \mathrm{~s} / \mathrm{d}$ 0,20 = tidak ada korelasi; nilai Pearson Correlation: 0,21 s/d 0,40 = korelasi lemah; nilai Pearson Correlation: $0,41 \mathrm{~s} / \mathrm{d}$ 0,60 = korelasi sedang; nilai Pearson Correlation: 0,61 s/d 0,80= korelasi kuat; Nilai Pearson Correlation: 0,81 s/d $1,00=$ korelasi sempurna.

\section{HASIL DAN PEMBAHASAN}

Penelitian ini dilakukan di dua wilayah kajian dengan karakteristik yang sangat berbeda. Wilayah kajian pertama adalah wilayah relokasi (wilayah baru dari orang 
terdampak yang disediakan oleh pemerintah sehingga penduduknya memiliki keseragaman yaitu semua orang terdampak) meliputi atas Kapling Mekar Asih dan Kapling Wado, dengan jumlah partisipannya mencapai 60 orang. Wilayah kajian kedua adalah wilayah sisipan (orang terdampak memilih tinggal di tengah-tengah penduduk desa lain yang tidak tergenang), orang terdampak di wilayah kajian ini lebih tersebar. Orang terdampak kelompok ini berasal dari Desa Wado Girang, Darmaraja, Ciranggem, dan Jemah, jumlah partisipannya mencapai 40 orang.

Secara umum temuan penelitian menunjukan bahwa sampai dengan tahun kedua setelah penggenangan, orang yang ada diwilayah relokasi memiliki dukungan sosial dan ketahanan sosial yang relatif lebih tinggi. dibandingkan dengan dukungan sosial dan ketahanan sosial orang terdampak yang ada di wilayah sisipan. Data mengenai dukungan sosial disekitar orang terdampak dan ketahanan sosial yang dimiliki orang terdampak nampak pada tabel 1 .

Perhitungan statistik dari pengaruh dukungan emosional terhadap ketahanan sosial menunjukan bahwa nilai korelasi/hubungan (R) yaitu sebesar 0,472. Dari output tersebut diperoleh koefisien determinasi ( $\mathrm{R}$ Square) 0,223 yang mengandung pengertian bahwa pengaruh variabel independent Emotional/ Informational Support (X1) terhadap variabel dependent Resiliensi (Y) sebesar 22,3\%. Selanjutnya Berdasarkan atas F hitung 28,151 dengan nilai signifikansi sebesar $0,000<0,05$ maka model regresi dapat digunakan untuk memprediksi pengaruh variabel independent

\section{Tabel 1 Tingkat Dukungan dan Ketahanan Sosial Di Wilayah Kajian}

\begin{tabular}{lllll}
\hline Dimensi & \multicolumn{2}{c}{ Wilayah Relokasi } & \multicolumn{2}{c}{ Wilayah Sisipan } \\
\cline { 3 - 5 } $\begin{array}{c}\text { Dukungan } \\
\text { Sosial }\end{array}$ & Tinggi & Sedang & Tinggi & Sedang \\
\hline Resiliensi & 86,7 & 13,3 & 62,5 & 37,5 \\
Emosional & 75 & 25 & 75 & 25 \\
Tangable & 71,7 & 28,3 & 67,5 & 32,5 \\
Affeksi & 85 & 15 & 65 & 35 \\
R e 1 a s i & 73,3 & 26,7 & 50 & 50 \\
positif & & & & \\
\hline
\end{tabular}

Sumber: Data Lapangan tahun 2017
Emotional/Informational Support (X1) terhadap variabel dependent resiliensi (Y). Perhitungan regresi menunjukan bahwa nilai Constant (a) sebesar 33,585, sedangkan nilai Emotional Support (b/koefisien regresi) sebesar 0,955. Diperoleh persamaan regresinya $\mathrm{Y}=33,585+$ $0,955 \mathrm{X}$, artinya setiap penambahan $1 \%$ nilai Emotional Support, maka nilai Resiliensi akan bertambah sebesar 0,955. Koefisien tersebut bernilai positif, maka dapat dikatakan pengaruh $\mathrm{X} 1$ terhadap $\mathrm{Y}$ adalah positif.

Secara umum nampak bahwa hasil penelitian mengenai pengaruh aspek dukungan emosional terhadap resiliensi orang terdampak pembangunan Jatigede, mendukung beberapa penelitian atau kajian yang sudah dilakukan seperti (House \& Kahn, 1985) dan penelitian lain yang memiliki kesejalanan mengenai pentingnya dukungan emosional dalam bidang kesehatan dapat dilihat melalui hasil risetnya (Price, Gros, Strachan, Ruggiero, \& Acierno, 2013). Sedangkan hasil penelitian lain yang menunjukan adanya kaitan dukungan emosial dengan rasa aman ditunjukan hasil kajiannya (Kessler, Price, \& Wortman, 1985) Kaitan dukungan emosional dalam mengatasi rasa negatif menurut (Boren, 2013) ditemukan pada kajian (Shumaker \& Brownell, 1984), (Allen, Mcmanus, \& Russell, 1999), (Shinn, Lehmann, \& Wong, 1984), (Viswesvaran, Sanchez, \& Fisher, 1999) serta (Caligiuri \& Lazarova, 2011), dukungan sosial mampu menengahi stres dikemukakan (Dirks \& Metts, 2010), (Stachour, 1998) dan (Jairam \& Kahl, 2012) serta dukungan emosional meningkatkan semangat (Burleson, Albrecht, \& Sarason, 1994).

Pengaruh dukungan nyata (variabel independent/Tangible Support) atau (X2) terhadap resiliensi (sebagai variabel dependent) atau (Y), perhitungan regresi sederhana menunjukan nilai korelasi/hubungan (R) sebesar 0,341. Dari output tersebut diperoleh pada koefisien determinasi (R Square) 0,116 yang mengandung pengertian bahwa pengaruh variabel independent Tangible Support (X2) terhadap variabel dependent Resiliensi (Y) sebesar $11,6 \%$. Berdasarkan atas pedoman derajat hubungan nilai $\mathrm{R}$ dari $\mathrm{X} 2$ terhadap $\mathrm{Y}$ sebesar 0,341 maka disimpulkan bahwa ada korelasi dukungan yang bersifat nyata terhadap resiliensi orang terdampak walau relasinya tinggi atau lemah.

Hasil perhitungan Anova menunjukan 
gambaran bahwa nilai $\mathrm{F}$ hitung 12,872 dengan nilai signifikansi sebesar $0,001<0,05$ ini berarti model regresi dapat digunakan untuk memprediksi pengaruh variabel independent Tangible Support (X2) terhadap variabel dependent Resiliensi (Y). Perhitungan selanjutnya menunjukan bahwa nilai Constant (a) sebesar 42,200, sedangkan nilai Tangible Support (b/koefisien regresi) sebesar 1,133. Sehingga persamaan regresinya dapat ditulis sbb:

$Y=42,200+1,133 X$, persamaan ini dapat dimaknai bahwa nilai konsistensi variabel Resilensi adalah 42,200 dan koefisien regresi $\mathrm{X}$ sebesar 1,133 menyatakan bahwa setiap penambahan 1\% nilai Emotional/Informational Support, maka nilai Resiliensi akan bertambah sebesar 1,133. Koefisien tersebut bernilai positif, maka dapat dikatakan pengaruh X1 terhadap Y adalah positif. Temuan penelitian menunjukan kesejalan dengan penelitian lain seperti (Henly, 2005) tentang dukungan tangible sebagai penyangga stressor kehidupan sehari-hari; dan penelitiannya (Price et al., 2013) mengenai bantuan.

Memberi dukungan bersifat nyata memang memberi pengaruh positif, akan tetapi beberapa pengkaji tetap mengingatkan mengenai perlunya kehati-hatian memberi dukungan ini. (Deininger \& Liu, 2009) berpendapat dukungan dapat melemahkan kapasitas lokal, juga temuan (Siedlecki, Salthouse, Oishi, \& Jeswani, 2013) bahwa dukungan dari orang lain dapat mengancam identitas orang tua dan rasa kompetensinya. Pemberian dukungan yang dinilai tepat atau bermanfaat menurut (Lord \& Hutchison, 1993) adalah saat mereka atau yang akan diberi dukungan mulai menyadari adanya alternatif.

Aspek yang juga perlu dipikirkan dan diperhatikan dalam pemberian dukungan adalah: Jenis dukungan yang diberikan; Kuantitas, waktu, dan/atau frekuensi dukungan yang diberikan; Apakah dukungan itu benarbenar diterima atau hanya dianggap tersedia; Kepuasan penerima dengan tingkat dukungan yang diberikan atau tersedia; Hubungan antara pihak-pihak yang terlibat; dan Apakah dukungan akan menjadi timbal balik (Pedrosa, Fiuza, Cunha, \& Reis, 2016) Jadi tanpa kehatihatian, dukungan nyata yang diberikan bisa bersifat kontraproduktif dengan tujuan dari pemberian dukungan.
Temuan penelitian selanjutnya terkait dengan pengaruh dukungan kasih sayang terhadap ketahanan orang terdampak dari pembangunan bendungan Jatigede menunjukan bahwa diperoleh nilai korelasi/hubungan (R) yaitu sebesar 0,396. Dari output tersebut diperoleh koefisien determinasi (R Square) 0,157 yang mengandung pengertian bahwa pengaruh variabel independent Affectionate Support (X3) terhadap variabel dependent Resiliensi (Y) sebesar 15,7\%. Pada nilai F hitung 18,212 dengan nilai signifikansi sebesar $0,000<0,05$ nilai Constant (a) sebesar 37,991, sedangkan nilai Affectionate Support (b/koefisien regresi) sebesar 1,834 . Sehingga persamaan regresinya $\mathrm{Y}=37,991+1,834 \mathrm{X}$, Persamaan tersebut dapat diterjemahkan bahwa setiap penambahan $1 \%$ nilai Affectionate Support, maka nilai Resiliensi akan bertambah sebesar 1,834. Koefisien tersebut bernilai positif, maka dapat dikatakan pengaruh X3 terhadap Y adalah positif. Temuan ini memperkuat teori, konsep ataupun temuan serta kajian-kajian sebelumnya. Seperti (González, 1998) bahwa kasih sayang sebagai bentuk batuan atau kerja sama untuk bertahan.

Aspek terakhir dari dukungan sosial yang dikaji adalah positif social interaction. Hasil perhitungan atas pengaruh positif social interaction terhadap resiliensi menunjukan bahwa nilai Constant (a) sebesar 47,985, sedangkan nilai Positive Social Interaction (b/koefisien regresi) sebesar 0,975. Sehingga persamaan regresinya dapat ditulis $\mathrm{Y}=47,985$ $+0,975 \mathrm{X}$. Ini bisa diartikan bahwa koefisien regresi X sebesar 0,975 menyatakan bahwa setiap penambahan $1 \%$ nilai Positive Social Interaction Support, maka nilai resiliensi akan bertambah sebesar 0,975. Koefisien tersebut bernilai positif, maka dapat dikatakan pengaruh X1 terhadap Y adalah positif.

Secara prinsip temuan riset mengenai interaksi sosial yang positif yaitu suatu “interaksi yang ditunjukan antara lain melalui pelibatan ataupun keterlibatan dalam aktivitas yang menyenangkan" Mendukung pemikiran ataupun hasil kajian beberapa ahli sebelumnya seperti kajian (Keck \& Sakdapolrak, 2013) yaitu "hubungan sosial positif menjadi landasan untuk membangun ketahanan sosial".

Beberapa hal menarik dari temuan penelitian ini adalah pengaruh tertinggi dari dimensi sosial yang diukur ada pada aspek emosional dan pengaruh yang terkecil dari dimensi yang 
diukur ada pada interaksi sosial positif. Kalau kondisi ini dikomparasikan dengan beberapa riset sebagaimana ditulis kembali oleh (Ozbay, 2007) yang mengurai bahwa dari dua dimensi dukungan sosial yaitu struktural salah satunya interaksi sosial dan dimensi fungsional emosional, hasil penelitian menunjukan bahwa sekalipun kedua dimensi penting akan tetapi dimensi fungsional menjadi prediktor yang lebih baik dibanding dimensi struktural. Ini bisa diartikan bahwa hasil penelitian yang dilakukan ini memiliki kesejalanan dengan penelitianpenelitian lain sebelumnya.

Temuan riset (Camara et al., 2015) menunjukanan bahwa dukungan emosial lebih unggul dibanding jenis dukungan lain walaupun dukungan emosiaonal itu sendiri (Griffiths, Crisp, Barney, \& Reid, 2011) dan lebih unggul dibanding bentuk dukungan lain walaupun dukungan emosional sendiri memang tidak besar.

Salah satu asumsi jawaban teoritik ataupun konseptual dari kondisi dimana dimensi struktural tidak menjadi prediktor yang lebih baik dari dimensi fungsional telah dikemukakan (Servaes, 2003) yang pada intinya bahwa interaksi sosial itu bisa mahal, membutuhkan waktu, uang, dan energi dan terkadang menimbulkan pengalaman yang tidak menyenangkan.

\section{SIMPULAN}

Hasil penelitian ini menunjukan bahwa dukungan sosial yang diberikan komunitas atau masyarakat memiliki pengaruh terhadap ketahanan orang-orang terdampak pembangunan Jatigede, dengan dimensi yang paling unggul ada pada dimensi dukungan emosional.

Sebagai konsekuensi dari temuan ini maka prioritas yang sebaiknya dilakukan guna memunculkan ketahanan sosial pada orang terdampak pembangunan Jatigede adalah selain melaksanakan pengembangan pada individu terdampak maka sangat penting adalah mendorong orang-orang yang ada disekitar (lingkungan sosial) orang-orang terdampak untuk berempati atau mau peduli serta mendorong orang-orang terdampak pembangunan Jatigede menjadi orang-orang yang lebih baik.

\section{DAFTAR PUSTAKA}

Allen, T. D., Mcmanus, S. E., \& Russell, J. E. A. (1999). Newcomer socialization and stress: formal peer relationships as a source of support. Journal of Vocational Behavior, 543(3), 453-470.

Anisa, R. (2016). Manajemen kerelasian pelanggan dalam menciptakan kepercayaan pelanggan pada commercial banking center Bandung PT. Bank Mandiri (persero) TBK. Jurnal Kajian Komunikasi, 4(1), 44-51.

Badri, S. A., Asgary, A., Eftekhari, A. R., \& Levy, J. (2006). Post-disaster resettlement, development and change: a case study of the 1990 Manjil earthquake in Iran. Overseas Development Institute, 30(4), 451-468.

Bakti, I., Dewi, E. A. S., Romli, R., \& Budiana, H. R. (2015). Analisis faktor personal pada sumber komunikasi dalam pengelolaan tanaman obat keluarga di Jawa Barat. Jurnal Kajian Komunikasi, 3(2), 133-139.

Boren, J. P. (2013). The relationships between co-rumination, social support, stress, and burnout among working adults. Management Communication Quarterly, 3-25.

Burleson, B. R., Albrecht, T. L., \& Sarason, I. G. (1994). Communication of social support: Messages, interactions, relationships, and community. Sage Publications.

Cadell, S., Karabanow, J., \& Sanchez, M. (2001). Community, empowerment, and resilience: Paths to wellness. Canadian Journal of Community Mental Health, 2135.

Caligiuri, P., \& Lazarova, M. (2011). The International journal of human resource management a model for the influence of socialinteractionand socialsupportonfemale expatriates ' cross-cultural adjustment. The International Journal of Human Resource Management, 13(5), 37-41. https://doi. org/10.1080/09585190210125903.

Camara, M., Bacigalupe, G., \& Padilla, P. (2015). The role of social support in adolescents: are you helping me or stressing me out? International Journal of Adolescence and Youth, 3843 (December). https://doi.org/10 .1080/02673843.2013.875480.

Cernea, M. M. (1997). Impoverishment risks, risk management, and reconstruction: A 
model of population displacement and resettlement. World Development, 27-290.

Chib, A., \& Wilkin, H. A. (2013). International migrant workers ' use of mobile phones to seek social support in Singapore. Informatios Technologies \& International Development, 9(4), 19-34.

Cline, R. J. W. (2016). Community-level social support responses in a slowmotion technological disaster: The case of Libby, Montana. Am Journal Community Psychology, (46 (0)), 1-18.

Cobb, S. (1976). Social support as a moderator of life stress. Psychosomatic Medicine Vol., $38(5)$.

Cohen, S. (2004). The stress-buffering hypothesis. Dalam N. B. Anderson, Encyclopedia of Health and Behavior. Sage Publications, 780-782.

Deininger, K., \& Liu, Y. (2009). Longer-term economic impacts of self-help groups in India. Policy Research Working Paper, (March), 1-29.

Dirks, S. E., \& Metts, S. (2010). An investigation of the support process: Decision, enactment, and outcome an investigation of the support process. Journal Communication Studie, (October 2014), 391-441. https://doi.org/1 0.1080/10510974.2010.491344.

Downing, T. E. (2002). Avoiding new poverty: Displacement and resettlement. International Institute for Environment and Development (IIED), (58).

Folke, C. (2016). Social-ecological resilience and biosphere-based sustainability science. Ecology and Society 2, 1(3), 41.

González, M. . (1998). What is affection?

Griffiths, K. M., Crisp, D. A., Barney, L., \& Reid, R. (2011). Seeking help for depression from family and friends: A qualitative analysis of perceived advantages and disadvantages. BMC Psychiatry, (11), 196.

Henly, J. R. (2005). The contribution of social support to the material well-being of lowincome families. Journal of Marriage and Family, 67(February), 122-140.

House, J., \& Kahn, R. (1985). Measures and concept of social support. American Psychological Association, 83-108.

Jairam, D., \& Kahl, D. H. (2012). Navigating the doctoral experience: The role of social support in successful degree completion.
International Journal of Doctoral Studies, 7, 311-329.

Keck, M., \& Sakdapolrak, P. (2013). WHAT IS SOCIAL RESILIENCE? LESSONS LEARNED AND WAYS FORWARD 1 Introduction. Erdkunde, 67(1), 5-19.https:// doi.org/10.3112/erdkunde.2013.01.02.

Kenneth, H., \& Karen, R. (1997). Distinguishing the theoretical functions of social ties: Implications for support interventions. American Psychological Association, 649670.

Kessler, R. C., Price, R. H., \& Wortman, C. B. (1985). Social factors in psychopathology: stress, social support, and coping processes. Annual Review of Psychology, (36), 531572.

Kirchherr, J., \& Charles, K. (2016). The Social Impacts of dams: A new framework for scholarly analysis. Environmental Impact Assessment Review., 1(1), 1-49.

Leary, K. A., \& Derosier, M. E. (2012). Factors promoting positive adaptation and resilience during the transition to college. Psychology, 3(12), 1215-1222.

Lerer, L. B. (1999). Health impacts of large dams. Environmental Impact Assessment Review, 9255(98), 113-123.

Lidahuli, S. G. (2015). Social and economic impacts of involuntary resettlement during large scalewater infrustructure development: The case of thika dam. Nairobi: University of Nairobi.

Lin, N., Dean, A., \& Ensel, W. M. (1985). Social support, life events, and depression. USA: Academic Press.

Lord, J., \& Hutchison, P. (1993). The process of empowerment: Implications for theory and practice the process of empowerment. Canadian Journal of Community Mental Healt, 12(1), 5-25.

Mccartney, M., Sullivan, C., \& Acreman, M. . (2001). Ecosystem impacts of large dams. UK: M.P., IUCN, UNEP or UNF.

Millicent, N., \& Jeff, B. (2008). Emotional and informational social support: Exploring contrasting influences on human resource management innovation. Journal of Organizational Culture, Communications and Conflict.

Mitchell, T. R. (1987). People in organizations: An introduction to organizational behavior 
(3rd ed.). New York: McGraw-Hill.

Norris, F. H. (2008). Community resilience as a metaphor, theory, set of capacities, and strategy for disaster readiness. Am $\mathrm{J}$ Community Psychol, (41), 127-150. https:// doi.org/10.1007/s10464-007-9156-6.

Nugraha, A. R., Sumartias, S., Novianti, E., \& Komariah, K. (2015). Implementasi kegiatan corporate social responsiblity 'go greeen economic' berbasiskan kearifan lokal. Jurnal Komunikasi, 7(2), 106-115.

Ozbay, F. (2007). Social support and resilience to stress: From neurobiology to clinical practice. Psychiatry, 4(5), 35-40.

Pedrosa, S. C., Fiuza, M. L. T., Cunha, G. H., \& Reis, R. K. (2016). Social support for people living with acquired immunodeficiency syndrome. Texto Contexto Enferm, 25(4), 2-8.

Pietkiewicz, I., Wojcik, M., Popiolek, K., \& Barika, A. (2015). Resources and adaptation following involuntary resettlement in the Bytom-Karb community. Polish Psychological Bulletin, 46(1), 15-25.

Price, M., Gros, D. F., Strachan, M., Ruggiero, K. J., \& Acierno, R. (2013). The role of social support in exposure therapy for operation iraqi freedom/ operation enduring freedom veterans: A preliminary investigation. A Preliminary Investigation. Psychol Trauma, 5(1), 93-100. https://doi. org/10.1037/a0026244.

Rakhmat, J. (2009). Metode penelitian kualitatif. Bandung: Rosdakarya.

Rosenholtz, S. J. (1989). Workplace conditions that affect teacher quality and commitment: Implications for teacher induction programs. The Elementary School Journal, 421-439.

S. B, M. (2014). Well-being of community disaster resilience. Bellingham: Western Washington University.

Schaefer, C., Coyne, J. C., \& Lazarus, R. S. (1981). The health-related functions of social support. Journal of Behavioral Medicine, 4(4), 381-382.

Servaes, J. (2003). Approaches to development: studies on communication for development. Paris: Communication and Information
Sector.

Sherbourne, C. D., \& Stewart, A. L. (1991). The mos social support survey. Social Science $\&$ Medicine, 32(6), 705-714.

Shields, M. . (2015). Social impact studies an expository analysis, 7(3), 265-284.

Shinn, M., Lehmann, S., \& Wong, N. W. (1984). Social interaction and social support. Journal of Social Issues, 40(4), 55-76.

Shumaker, S. A., \& Brownell, A. (1984). Toward a theory of social support: Closing conceptual gaps. Journal of Social Issues, 40(4), 11-36.

Siedlecki, K. L., Salthouse, T. A., Oishi, S., \& Jeswani, S. (2013). and Subjective wellbeing across age. Social Indicators Researc, 117(2), 561-576. https://doi.org/10.1007/ s11205-013-0361-4.

Singh,K.,\&Billingsley,B.S.(2010).Professional support and its effects on teachers' commitment. The Journal of Educational Research, (October 2014), 37-41. https:// doi.org/10.1080/00220679809597548.

Sippel, L. M., Pietrzak, R. H., Mayes, L. C., \& Southwick, S. M. (2015). How does social support enhance resilience in the traumaexposed individual? Ecology and Society, 20(4).

Southwick, S. M., Litz, B. T., Charney, D., \& Friedman, M. J. (2011). Resilience and mental health: Challenges across the lifespan. Cambridge University Press.

Stachour, V. M. (1998). The role of social support in mediating stress and illness. In Paper (pp. 2-36).

UNDP. (2013). Promoting sustainable livelihoods, reducing vulnerability and building resilience in the drylands.

Viswesvaran, C., Sanchez, J. I., \& Fisher, J. (1999). The role of social support in the process of work stress: A meta-analysis. Journal of Vocational Behavior, 54(2), 314-334.

Westley, F., Olsson, P., Folke, C., Homerdixon, T., Vredenburg, H., Loorbach, D., Leeuw, S. Van Der. (2011). Tipping toward sustainability: emerging pathways of transformation. Ambio, 762-780. https:// doi.org/10.1007/s13280-011-0186-9. 